WIDER Working Paper 2019/42

\title{
Inequality in India
}

A review of levels and trends

Himanshu*

May 2019 
Abstract: This paper contributes to the literature by reviewing levels, trends, and structure of inequality since the early $1990 \mathrm{~s}$ in India. It draws extensively on the existing literature, supplemented with analyses of multiple data sources, to paint a picture. It notes where different data sources suggest conflicting conclusions that reflect both data challenges and the complexity of the underlying drivers of inequality changes. While the primary focus is on examining trends based on standard economic indicators of income/consumption and wealth, the paper briefly reviews distributions of selected non-monetary indicators, such as education and health.

Keywords: consumption, data challenges, inequality, income, non-monetary indicators, wealth

Acknowledgements: We would like to acknowledge comments/suggestions received from participants in the workshop on 'Inequality in India', held on 13 April 2018 at the Centre de Sciences Humaines, New Delhi. We are also grateful to Finn Tarp and Peter Lanjouw for encouraging us to work on this paper, as well as for helpful comments and suggestions on improving the paper. The views expressed in this paper are the author's and do not represent the views of the organization they represent.

*Jawaharlal Nehru University, New Delhi, India, himanshu2@gmail.com

This study has been prepared within the UNU-WIDER project on 'Inequality in the Giants'.

Copyright (C) UNU-WIDER 2019

Information and requests: publications@wider.unu.edu

ISSN 1798-7237 ISBN 978-92-9256-676-0 https://doi.org/10.35188/UNU-WIDER/2019/676-0

Typescript prepared by Merl Storr.

The United Nations University World Institute for Development Economics Research provides economic analysis and policy advice with the aim of promoting sustainable and equitable development. The Institute began operations in 1985 in Helsinki, Finland, as the first research and training centre of the United Nations University. Today it is a unique blend of think tank, research institute, and UN agency — providing a range of services from policy advice to governments as well as freely available original research.

The Institute is funded through income from an endowment fund with additional contributions to its work programme from Finland, Sweden, and the United Kingdom as well as earmarked contributions for specific projects from a variety of donors.

Katajanokanlaituri 6 B, 00160 Helsinki, Finland

The views expressed in this paper are those of the author(s), and do not necessarily reflect the views of the Institute or the United Nations University, nor the programme/project donors. 
Recent years have seen a rise in interest in understanding trends and dimensions of inequality across countries as well as within countries (Atkinson 2015; Milanovic 2016; Piketty 2014; Stiglitz 2012). Multilateral institutions such as the World Bank (2016; Lange et al. 2018), International Monetary Fund (IMF 2017), and Asian Development Bank (Kanbur et al. 2014) have raised flags regarding the nature and consequences of rising inequality across and within countries for growth and poverty reduction. The United Nations has also included inequality reduction as one of the Sustainable Development Goals. ${ }^{1}$

While much of the discussion of inequality has revolved around trends in inequality across nations and within industrialized countries, it has also changed its focus, from inequality as a purely empirical and distributional issue to the changing nature of inequality and its impact on growth and mobility. Some of these questions are also relevant for emerging countries such as India and China, where rapid growth in per-capita incomes has been accompanied not only by rising income inequality, but also by rising disparities between social and economic groups, and between labour and capital. The relationships between labour market outcomes, fiscal policies and tax structures, redistributive transfers, and capital market regulations are not just outcomes of economic policy, but are also driven by existing social and political structures. This is even more so in a society where access to health, education, nutrition, and other public services is not universal but governed by race, caste, religion, gender, and residence.

Some of these issues have found resonance in India, with the issue of inequality becoming important in academic and public debates. However, compared with debates on poverty, inequality in India has received less attention from academics as well as policymakers. This is partly because, in a developing country, poverty - particularly extreme poverty-commands more attention than inequality, in policy circles and academic debates alike. But it is also because of a lack of appropriate data on income distribution in the country. Even though India has a long history of data collection on consumption expenditure, which has formed the basis of poverty estimations, inequality has continued to be underestimated, or at least to be seen as less of a problem. However, there is now strong evidence to suggest that inequality in India is not only very high but has also increased during a period of accelerating income growth, particularly since 1991. Despite the limitations on data availability, a number of studies have analysed the trends in inequality. ${ }^{2}$

The literature on inequality has not only looked at various issues related to the measurement of inequality using different data sources, but has also been instrumental in developing an understanding of the nature and causes of inequality in India (Chancel and Piketty 2017; Himanshu 2007, 2015; Mazumdar et al. 2017a, 2017b; Sarkar and Mehta 2010; Sen and Himanshu 2004; Subramaniam and Jayaraj 2006). Based on data available up until 2011-12, the overwhelming consensus is that not only is inequality very high in India compared with other countries at similar levels of economic development, but it has also shown a rising trend over time, particularly since the early 1990s. While the rate of rise in inequality seems to have slowed down after 2004-05, it continues to show a rising trend. Existing literature has also highlighted the role of caste, gender, region, and religion in perpetuating inequality.

\footnotetext{
${ }^{1}$ The Sustainable Development Goals, adopted by the United Nations General Assembly in September 2015, ask member states to reduce economic inequalities by 2030 .

${ }^{2}$ For a journalistic account of inequality in India, see Crabtree (2018).
} 
Much of the analysis of inequality in recent years has focused on trends in inequality in recent decades, particularly after 1991, which suggests that the trend break of liberalization in 1991 contributed to a trend of rising inequality. This is further obvious when compared with the trend in inequality in the decade before 1991, which shows not only an acceleration in growth rates but also a decline in inequality and poverty. Unlike the 1980s, which saw growth accelerate in the economy alongside declining inequality, the period after 1991 clearly shows inequalities rising throughout. While there is some moderation in the rise in inequality after 2004-05-which is also the period of fastest decline in poverty in the last three decades - this does not suggest a break in the structure and pattern of growth that contributed to the rise in inequality after 1991.

The purpose of this paper is to analyse the rise in inequality not just in terms of its impact on future economic growth and distribution, but also in terms of social and political stability in a country such as India, which has a high level of horizontal inequalities based on caste, class, religion, race, gender, and location. ${ }^{3}$ Horizontal inequalities are embedded in social and political structures and affect citizens' access to basic services. Inequality in India is about education, health, nutrition, sanitation, and opportunities as much as it is about rising income inequality. It is difficult to quantify these aspects of horizontal inequality. Nonetheless, available evidence suggests similar rises in inequality in these dimensions. The burden of these disparities is not borne uniformly across groups or across different generations. Historically marginalized groups such as Dalits (Schedule Castes, SCs ${ }^{4}$ ), tribal groups (Schedule Tribes, $\mathrm{STs}^{5}$ ), and Muslims are disadvantaged not only as regards access to wealth and employment opportunities, but also regarding access to basic services, which then leads to lower levels of health, nutrition, and education. Even within these disadvantaged groups, patriarchal norms and social structures have led to women being further excluded from access to basic services.

This paper presents an analysis of trends in inequality in several dimensions in India in recent decades. While the focus is on examining trends based on the standard economic indicators of income, consumption, and wealth, we also extend the analysis to examine them by social group, residence, region, religion, and gender. Although we examine these trends in detail for the last three decades, we extend the analysis to earlier decades wherever data permits. Section 2 presents trends in inequality based on the standard indicators. We also provide some evidence on inequality from micro-surveys at the level of villages. While these more or less confirm the trend observed in nationally representative data, we present some aspects of inequality based on stand-alone and longitudinal village surveys. Using tax data from the World Inequality Database, we present the nature and extent of income/wealth concentration at the top of the income distribution.

Section 3 presents trends in inequality in other dimensions, including inequality in human development indicators. We look at different dimensions of access and achievement on indicators of health, education, and nutrition to examine trends in inequality in human development

\footnotetext{
${ }^{3}$ Stewart (2002) defines horizontal inequalities as inequalities arising from the social position of an individual in a society based on caste, race, and gender.

${ }^{4}$ SCs are the lowest caste group in the caste hierarchy. Previously described as 'untouchables', they have been victims of discrimination over centuries. Apart from untouchability, they have systematically been denied access to education and employment beyond the level at which they have been born. This changed with the introduction of reservation after independence. The reservation system allows SCs representation in public education and employment proportional to their population in the country.

${ }^{5}$ STs are tribal groups as notified by the Constitution. These groups have historically been excluded from the mainstream, and have been disadvantaged in terms of access to education and employment. Similarly to the SC groups, they are also beneficiaries of the reservation system in public education and employment, proportional to their population share.
} 
indicators. Most of the analysis in this section is based on large-scale surveys and official statistics. Section 4 presents some preliminary analysis of the changes in inequality measured in the last three decades. Although the attempt in this section is preliminary, we take the opportunity to highlight some of the proximate factors that have contributed to rising inequality in recent decades. Section 5 presents some concluding reflections.

\section{Monetary inequality: consumption, income, and wealth}

We begin our analysis of inequality in India using standard indicators of consumption, income, and wealth. While consumption and income measure a flow of resources over time, wealth (generally measured as net worth) refers to a stock of resources at a given point in time. Between consumption and income, consumption is considered a more accurate reflection of living standards, as households tend to smooth consumption flows over time. Consumption data are also easier to collect in economies with very large informal sectors. Throughout this section, data availability and quality call for caution in drawing definitive conclusions on the extent and trend of inequality.

\subsection{Consumption inequality}

India has a long series of national household surveys suitable for tracking household consumption since the early 1950s. In this paper we rely on the 'thick' rounds (with larger sample sizes) of the Indian National Sample Survey Office's (NSSO) National Sample Surveys (NSS) to examine trends since the early 1980s. Our measures are based on the mixed recall period (MRP) consumption aggregates that are the basis of India's official poverty estimates. ${ }^{6}$

A commonly used indicator of inequality is the Gini index, which varies from zero (in a context of perfect equality) to one (when one household accounts for all the consumption in the country). By this measure, inequality declined between 1983 and 1993-94 but rose appreciably in the following decade after the onset of reforms in 1991 (Table 1). Post-2005, inequality increased slightly or remained stable, depending on the indicator being considered. Other indicators that emphasize differences between the extremes of the consumption distribution, such as the ratio between the richest and poorest deciles, confirm rising inequality during period between 1993-94 and 2004-05, and smaller increases thereafter. In 2011-12, the richest 20 per cent of the population accounted for nearly 45 per cent of total consumption.

The inequality levels illustrated in Table 1 are likely to be overstated, as they are based on nominal consumption expenditure that does not correct for cost-of-living differences between states, or between rural and urban areas. Table 2, which reports Gini indices after correcting for cost-ofliving differences using the deflators implicit in the official poverty lines, shows indeed that inequality levels are lower. However, trends in inequality are preserved. Estimates based on the variance of $\log$ of consumption expenditure-which gives greater weight to inequality at the extremes-produce similar trends.

\footnotetext{
${ }^{6}$ Most NSS consumption rounds collect data using a uniform recall period (URP) of 30 days for all consumption items. An MRP aggregate with longer recall (365 days) for some (mainly non-food) items was introduced, alongside URP consumption, in the mid-2000s. For earlier years, we reconstruct a comparable MRP aggregate using the unit record data.
} 
Table 1: Recent trends in consumption inequality

\begin{tabular}{llllll}
\hline & 1983 & $1993-94$ & $2004-05$ & $2009-10$ & $2011-12$ \\
\hline Share of groups in total national consumption expenditure & & & \\
Bottom 20\% & 9.0 & 9.2 & 8.5 & 8.2 & 8.1 \\
Bottom 40\% & 22.2 & 22.3 & 20.3 & 19.9 & 19.6 \\
Top 20\% & 39.1 & 39.7 & 43.9 & 44.8 & 44.7 \\
Top 10\% & 24.7 & 25.4 & 29.2 & 30.1 & 29.9 \\
\hline Ratio of average consumption of groups & & & & 13.9 & 14.0 \\
Urban top 10\%/rural bottom 10\% & 9.5 & 9.4 & 12.7 & 13.1 \\
Urban top 10\%/urban bottom 10\% & 7.0 & 7.1 & 9.1 & 10.1 & 10.2 \\
Urban top 10\%/rural bottom 40\% & 6.5 & 6.8 & 9.4 & 10.1 & 0.29 \\
\hline Gini index & & & & 0.29 & 0.38 \\
Rural Gini & 0.27 & 0.26 & 0.28 & 0.38 & 0.37 \\
Urban Gini & 0.31 & 0.32 & 0.36 & 0.35 & 0.36 \\
All-India Gini & 0.30 & 0.30 & & & \\
\hline
\end{tabular}

Note: All estimates are based on MRP consumption aggregates.

Source: authors' calculations based on NSS data.

Table 2: Inequality trends in real consumption expenditure

Gini coefficient of consumption expenditure

\begin{tabular}{lllllll} 
& \multicolumn{2}{c}{ Nominal MPCE } & \multicolumn{3}{c}{ Real MPCE } \\
& Rural & Urban & Total & Rural & Urban & Total \\
$1993-94$ & 0.26 & 0.32 & 0.30 & 0.25 & 0.31 & 0.28 \\
$2004-05$ & 0.28 & 0.36 & 0.35 & 0.27 & 0.36 & 0.31 \\
$2009-10$ & 0.29 & 0.38 & 0.36 & 0.27 & 0.38 & 0.32 \\
$2011-12$ & 0.29 & 0.38 & 0.37 & 0.27 & 0.37 & 0.33 \\
\hline Variance of log of consumption expenditure & & & & Real MPCE \\
& & Nominal MPCE & & Urban & Total \\
1993-94 & 0.20 & 0.31 & 0.26 & 0.19 & 0.29 & 0.23 \\
$2004-05$ & 0.22 & 0.39 & 0.32 & 0.21 & 0.37 & 0.26 \\
$2009-10$ & 0.24 & 0.42 & 0.35 & 0.21 & 0.40 & 0.29 \\
$2011-12$ & 0.25 & 0.41 & 0.36 & 0.21 & 0.39 & 0.29 \\
\hline
\end{tabular}

Note: Real mean per-capita expenditures (MPCE) are MRP consumption estimates corrected for cost-of-living differences across states, rural and urban areas, and over time, using deflators implicit in the official poverty lines.

Source: authors' calculations based on NSS data. 
Examining growth rates of consumption at different points in the consumption distribution through an index of real mean per-capita expenditures (MPCE) further illustrates the emergence of a gap post-1993-94 (Figure 1). Between 1983 and 2011-12, while the urban poorest 40 per cent witnessed an increase of real MPCE by 51 per cent, MPCE for the urban top 20 per cent nearly doubled. Trends of MPCE growth also show that inequality grew faster in urban than in rural areas.

Figure 1: Index of real MPCE by groups $(1983=100)$

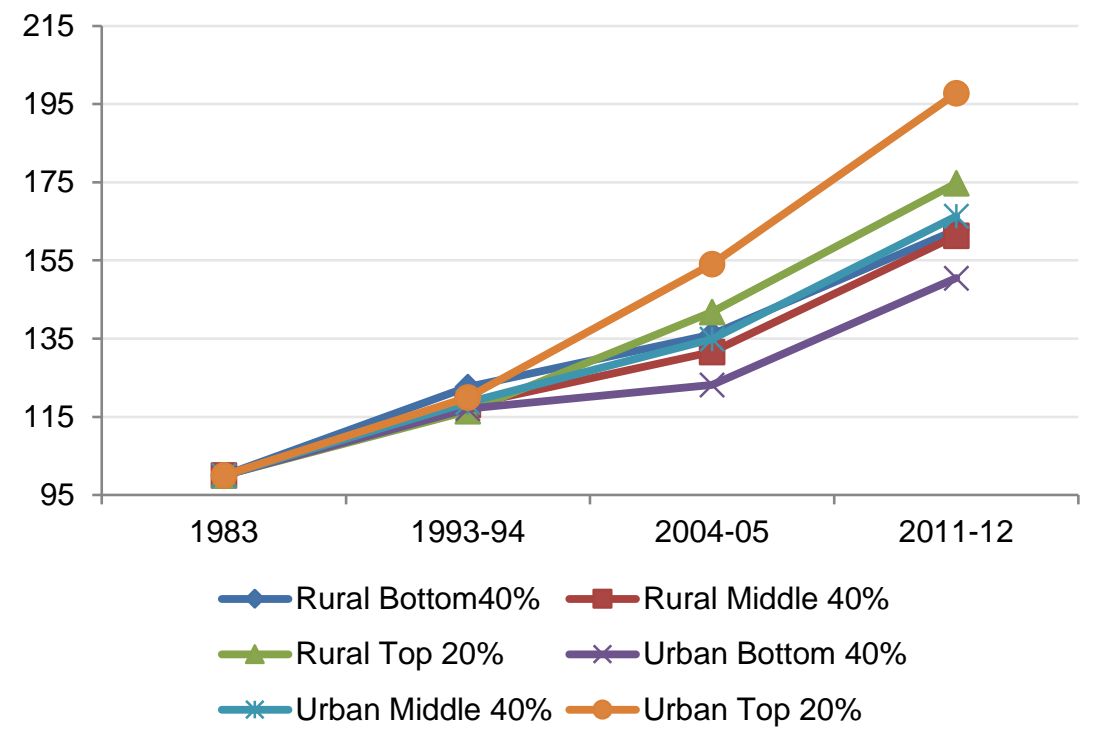

Note: Real MPCE are MRP consumption estimates corrected for cost-of-living differences across states, rural and urban areas, and over time, using deflators implicit in the official poverty lines.

Source: authors' calculations based on NSS data.

An important note of caution in assessing levels and trends in NSS-based consumption inequality is that household surveys may not capture well the consumption of richer households. One indication of this is the large and growing gap over time between aggregate consumption in surveys and private consumption in the Government of India's National Accounts Statistics (NAS). There are good reasons why the two aggregates should differ (for instance, due to differences in definitions of consumption), but the gap in India is large. ${ }^{7}$ It is difficult to know how much of the gap is due to errors in NAS versus NSS survey methods, with evidence of errors on both sides. To the extent that under-reporting of consumption or non-compliance is likely to be greater among the rich, inequality would be underestimated. Evidence from tax data (discussed later in this section) is consistent with this expectation.

\footnotetext{
${ }^{7}$ The ratio of NSS-to-NAS consumption declined from about 60 per cent in 1991 to 39 per cent in 2011-12 (Datt et al. 2016).
} 


\subsection{Income inequality}

Measuring inequality based on income yields a very different picture. Figure 2 reports Gini indices of consumption and income inequality from the 2004-05 and 2011-12 India Human Development Surveys (IHDS). The IHDS is a nationally representative household panel survey that collects comprehensive information on both consumption and income. Estimates based on this survey indicate that income inequality in India was about 0.54 in both 2004-05 and 2011-12, with a marginal increase during this period. ${ }^{8}$ As in the NSS, consumption inequality increased over time but is significantly lower than income inequality.

Figure 2: Inequality of consumption versus income

Gini index of consumption

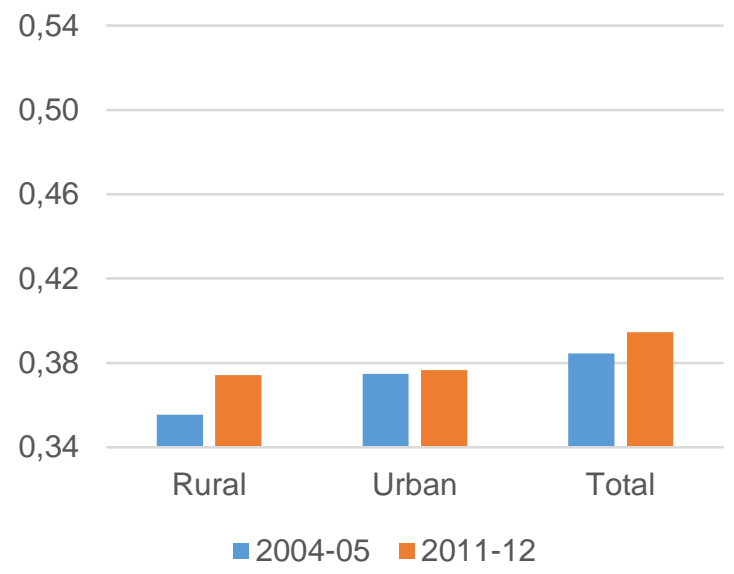

Gini index of income

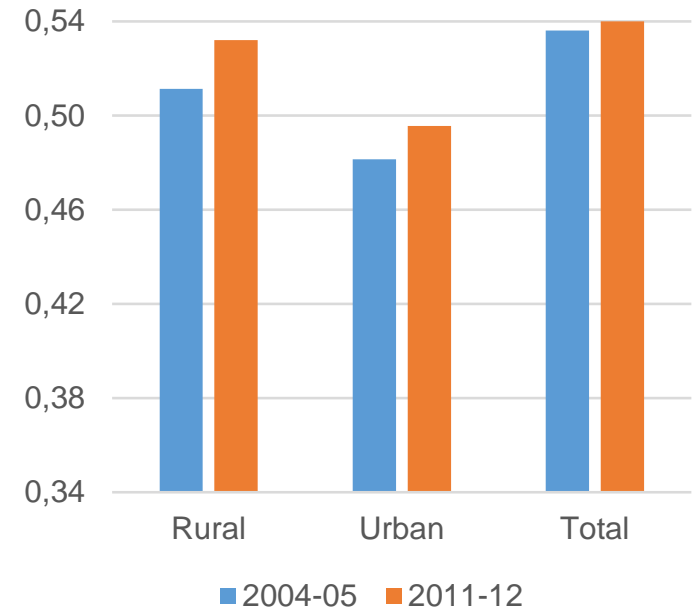

Source: authors' calculations based on IHDS data.

If India has modest levels of inequality based on its consumption Gini index, the income Gini of 0.54 in 2011-12 places it alongside the most unequal countries in the world. ${ }^{9}$ Across countries, income-based Gini indices tend to be higher than those based on consumption. Why the gap between India's consumption and income Gini measures of inequality is so large remains to be explained, ${ }^{10}$ but this finding at minimum casts doubt on the often-rehearsed notion that inequality is low in India. It also serves as a useful reminder of the difficulty of making international inequality comparisons, a difficulty too often overlooked when cross-country comparisons and regressions are undertaken.

\footnotetext{
${ }^{8}$ Corrected for spatial price differentials, the Gini coefficient of real incomes is 45.3 in 2005 and 45.9 in 2012.

9 The World Bank's (2018) database of Gini indices from 182 countries for 2005-15 shows only five- Botswana, Honduras, Namibia, South Africa, and Zambia - with higher income inequality than India. Of these, all except Zambia show a decline in inequality in the last decade, compared with India, which has reported a marginal increase.

${ }^{10} \mathrm{Li}$ et al. (1998) find that Gini indices based on consumption are systematically lower than income-based Ginis, with an average gap across countries of 6.6 Gini points.
} 


\subsection{Earnings inequality}

The NSSO conducts specialized surveys that provide estimates of income for some categories of workers. One such series is the NSS Employment-Unemployment Surveys (EUS), which collect information on weekly earnings of waged workers. The EUS data do not include information on the earnings of the self-employed-who comprise nearly half of all workers. Thus, wage inequality measures are only a partial reflection of the level of inequality in incomes.

Consistent with trends in consumption inequality, estimates of the Gini coefficient of wage earnings by Rodgers and Soundararajan (2015) show a marked increase between 1993-94 and 2004-05 (Figure 3). However, unlike consumption, between 2004-05 and 2011-12 wage inequality fell back to 1993-94 levels, likely due to the sharp rise in wages for rural unskilled labour during this period. Between 2008 and 2013, real wages for casual labour increased by more than six per cent per annum, faster than the growth of per-capita incomes (Himanshu 2018).

Figure 3: Trends in wages and wage inequality

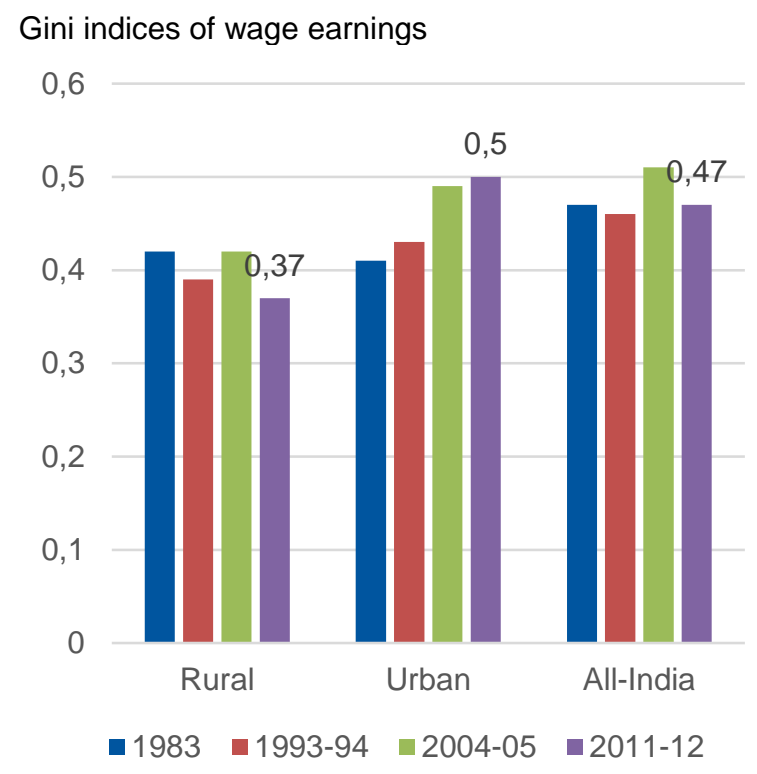

Trends in real wages for unskilled labour

Real Wages Unskilled labour (2011-12 prices)
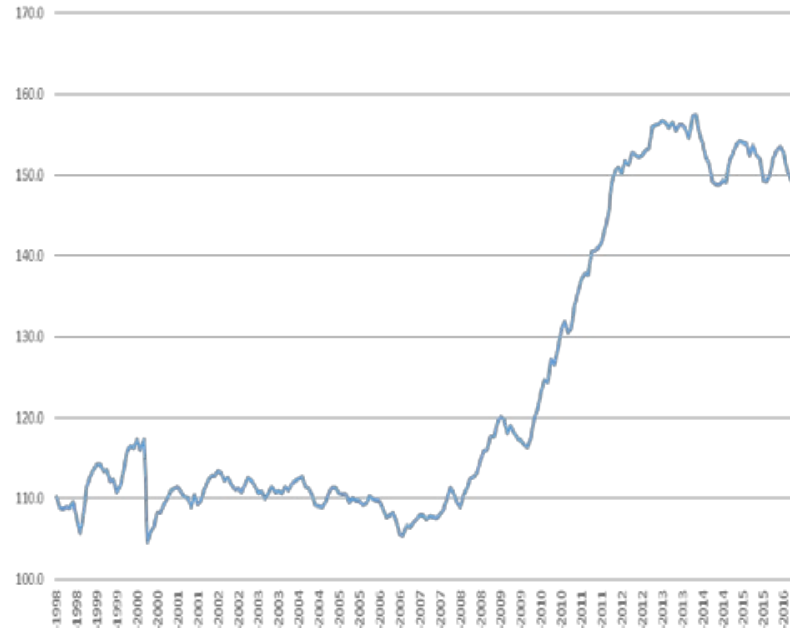

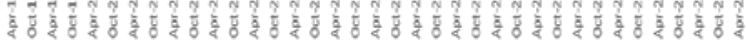

Source: left-hand panel, authors' estimates based on data from NSSO; right-hand panel, authors' estimates based on Wage Rates in Rural India data from Government of India, Labour Bureau.

A second source of data are the NSSO's Situation Assessment Surveys (SAS) of farmers, which are available for 2002 and 2012. Using these data, Chakravorty et al. (2016) report high levels of income inequality (a Gini index of 0.58 in 2012) among farmers. This is similar to the level $(0.60$ Gini points) estimated in the IHDS, and significantly higher than earnings inequality in most other occupational groups. It is also interesting to note that, similarly to results on wage inequality, the SAS data suggest that earnings inequality within the group of cultivators declined from 0.63 to 0.58 in the decade 2002-2012. ${ }^{11}$

\footnotetext{
${ }^{11}$ Note, however, that while levels of inequality from these surveys are similar to estimates from the IHDS, the latter suggests that earnings inequality among cultivators increased from 0.57 to 0.60 between 2004-05 and 2011-12. The differences could be due to the different definition of 'farmer' adopted by the NSSO surveys. Unlike the IHDS, which includes everybody who claims to be a farmer, the definition of 'farmer' in NSSO surveys excludes farmers below the income of INR 3,000.
} 
It is of course possible for the overall income Gini index to remain unchanged or rise even if inequality within particular groups declines. The overall Gini takes into account differences between groups, and would also reflect rising inequality within other occupation groups. One indication of this can be seen in Table 3. Between 2004-05 and 2011-12, a growing share of the population relied on non-agricultural labour for their earnings, and inequality within this group rose markedly. The share of the population dependent on non-agricultural labour grew significantly, from 18 per cent to 24 per cent. Rising top incomes not captured in household survey data would also be consistent with rising overall inequality.

Table 3: Income inequality by occupational group

\begin{tabular}{lllllll}
\hline Income source & $2004-05$ & & & $2011-12$ & & \\
& Pop. share & Income share & Gini & Pop. share & Income share & Gini \\
Cultivation & 0.284 & 0.207 & 0.57 & 0.261 & 0.200 & 0.60 \\
Allied ag. & 0.010 & 0.008 & 0.57 & 0.010 & 0.007 & 0.54 \\
Ag. labour & 0.144 & 0.072 & 0.36 & 0.104 & 0.060 & 0.41 \\
Non-ag. labour & 0.177 & 0.105 & 0.37 & 0.237 & 0.154 & 0.41 \\
Artisan & 0.057 & 0.055 & 0.45 & 0.017 & 0.015 & 0.43 \\
Petty trade & 0.042 & 0.042 & 0.42 & 0.115 & 0.120 & 0.51 \\
Business & 0.058 & 0.104 & 0.52 & 0.013 & 0.037 & 0.64 \\
Salaried & 0.171 & 0.327 & 0.44 & 0.175 & 0.318 & 0.47 \\
Profession & 0.009 & 0.013 & 0.57 & 0.005 & 0.009 & 0.57 \\
Pension/rent & 0.028 & 0.048 & 0.48 & 0.039 & 0.059 & 0.48 \\
Others & 0.021 & 0.020 & 0.53 & 0.025 & 0.021 & 0.49
\end{tabular}

Note: Inequality estimates are based on nominal income. Income sources are primary income source for the household.

Source: authors' calculations based on IHDS data.

\subsection{Wealth inequality}

The distribution of wealth provides a complementary perspective on consumption and income inequality. The All-India Debt and Investment Surveys (AIDIS), conducted in 1991, 2002, and 2012 by the NSSO, collected information on asset holdings and debts of households. Information is available in AIDIS on physical quantities of eight broad types of assets (e.g., land, buildings, agricultural machinery, vehicles, financial assets, debt) and their value. These are a useful source of information, with the caveat that values of assets are self-reported and there may be underreporting, particularly by richer households. To compare trends over time, we exclude durables from the estimation of net worth in the 1991 and 2002 surveys, as these data were not collected in the 2012 round. The analysis is based on nominal values, due to the lack of a suitable deflator. This information suggests much higher levels of inequality than in either consumption or income. The Gini coefficient based on AIDIS data for wealth (asset holdings) is 0.75 for 2012, rising from 0.66 in 1991 to 0.67 in 2002 (Figure 4) (see also Jayadev et al. 2007; Subramanian and Jayraj 2006; Vaidyanathan 1993). Trends and levels of inequality in net worth are similar. 
Figure 4: Gini coefficient of wealth (asset holdings)

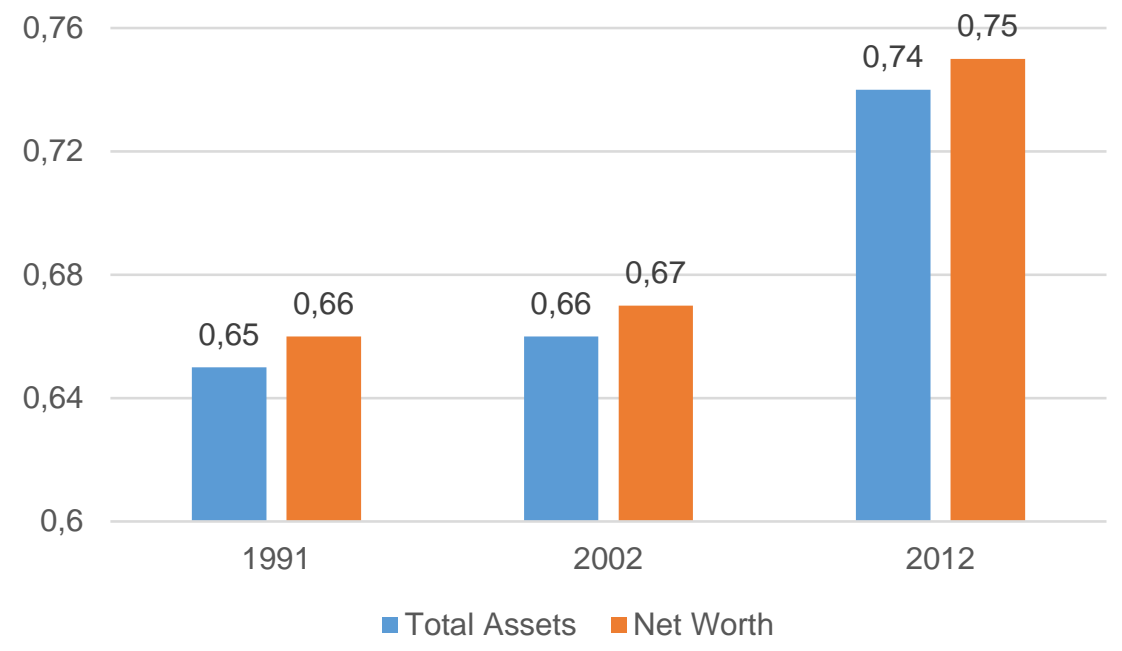

Source: authors' calculations based on AIDIS data.

The share of wealth held by different groups of the population (defined by asset-holding deciles) provides an alternative lens on wealth inequality (Table 4). The bottom 50 per cent of the population held nine per cent of total assets in the country in 1991, but saw their share decline by one third to only 5.3 per cent by 2012. Against this, the share of wealth held by the top one per cent increased from 17 per cent in 1991 to 28 per cent by 2012. The top 10 per cent held more than 50 per cent of wealth in all the survey years reported here, with the share rising from 51 per cent in 1991 to 63 per cent in 2012. Since estimates from AIDIS exclude information on bullion and durables, the share of wealth held by the top one per cent and top 10 per cent is likely to be higher once these are included. Also, since AIDIS does not include corporate wealth, in all likelihood the share of the top one per cent is an underestimate.

Table 4: Decile-wise share of wealth

\begin{tabular}{llcc}
\hline $\begin{array}{l}\text { Wealth } \\
\text { decile }\end{array}$ & \multicolumn{2}{c}{ Percentage share of total wealth } \\
Poorest $10 \%$ & 0.2 & 2002 & 2012 \\
$2^{\text {nd }}$ & 0.9 & 0.1 & 0.03 \\
$3^{\text {rd }}$ & 1.7 & 0.6 & 0.4 \\
$4^{\text {th }}$ & 2.6 & 1.3 & 0.9 \\
$5^{\text {th }}$ & 3.8 & 2.2 & 1.6 \\
$6^{\text {th }}$ & 5.2 & 3.2 & 2.4 \\
$7^{\text {th }}$ & 7.3 & 4.7 & 3.6 \\
$8^{\text {th }}$ & 10.4 & 6.8 & 5.3 \\
$9^{\text {th }}$ & 16.5 & 10.2 & 8.3 \\
Richest $10 \%$ & 51.6 & 17.2 & 15.0 \\
Top 1 \% & 16.9 & 53.9 & 62.5 \\
\hline
\end{tabular}

Source: authors' calculations based on AIDIS data.

The fact that wealth distribution is more concentrated than income or consumption is not surprising and is seen across countries. But international comparisons based on the AIDIS data and standardized for comparability, reported in Credit Suisse's annual Global Wealth Reports 
(GWR), suggest that India is an outlier (Credit Suisse 2016). ${ }^{12}$ The GWR estimates that the bottom 50 per cent of the Indian population held 8.1 per cent of total wealth in 2002, which declined to 4.2 per cent by 2012. In contrast, the top one per cent of the population held 15.7 per cent of total wealth in 2002, which increased to 25.7 per cent of total wealth by 2012. Among the countries for which the GWR gives the share of wealth held by the top one per cent, only those in Indonesia and the United States have a higher share of wealth than India.

\subsection{Further evidence on top incomes}

Other studies have used income tax data, in combination with household survey-based income or consumption data, to examine the changing shares of income accruing to rich households across a range of countries. For India, Chancel and Piketty (2017) have extended an earlier analysis by Banerjee and Piketty (2005) to develop a time series from 1922 to the present.

Similarly to trends in the United States, United Kingdom, and France, their results suggest that income inequality in India declined sharply between the 1950s and 1980s but increased thereafter (Figure 5). The share of income of the top one per cent reached a high of 21 per cent in the preindependence period, but declined subsequently until the early 1980s to reach six per cent. During this period, the bottom 50 per cent and top 10 per cent received nearly equal shares of income, at 28 per cent and 24 per cent respectively. Income shares of individuals in the middle of the distribution $\left(50^{\text {th }}-90^{\text {th }}\right.$ percentiles $)$ were also on the rise.

These trends reversed in the 1980s. The income share of the top one per cent increased, reaching 22 per cent in the most recent year for which estimates are available. The share of the top 0.1 per cent in national incomes is now at the highest level of nine per cent. While the bottom 50 per cent of earners experienced a growth of 97 per cent between 1980 and 2014, the top 10 per cent saw a 376 per cent increase in their incomes. During the same period, the very richest Indians, in the top 0.01 per cent and top 0.001 per cent, did extraordinarily well, with incomes rising by 1,834 per cent and 2,776 per cent respectively.

The World Inequality Lab (2018) also points out that the rise in share among top incomes in India has been faster than most countries. By 2016, India was second only to the Middle Eastern countries in the high-income share of the top 10 per cent. It was also the country with the highest increase in the share among top incomes in the last 30 years, with the share of the top 10 per cent increasing from 31 per cent in 1980 to 56 per cent in 2016.

\footnotetext{
12 The GWR wealth data for India are based on AIDIS, but are further refined using regression techniques to fill the gap for intervening years. The GWR also uses external data to rescale the wealth estimates.
} 
Income share of top $1 \%$

25

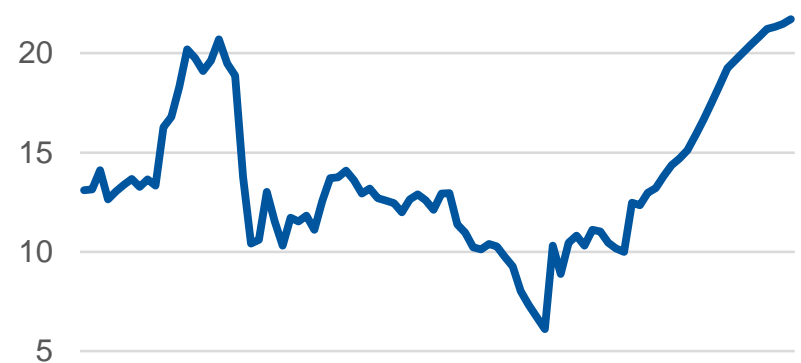

0

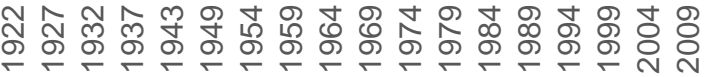

Income share of bottom $50 \%$

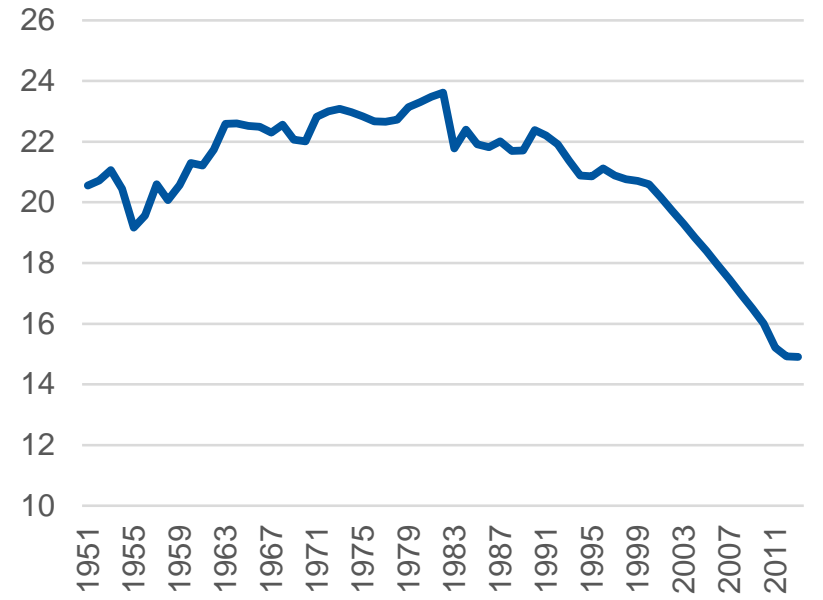

Income share of top $0.1 \%$

10

8

6

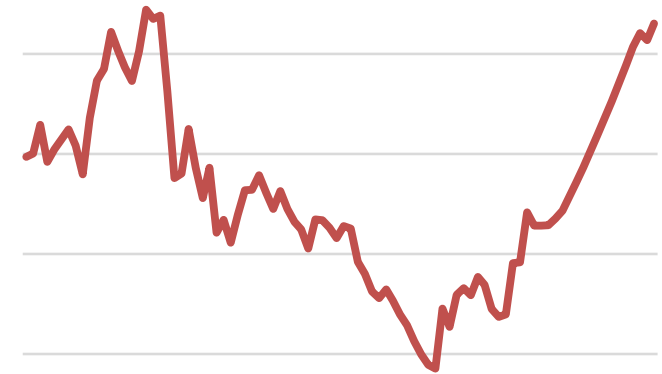

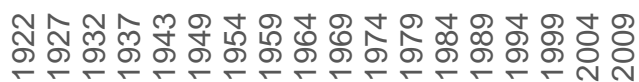

Income share of middle ( $50^{\text {th }}-90^{\text {th }}$ percentile)

50

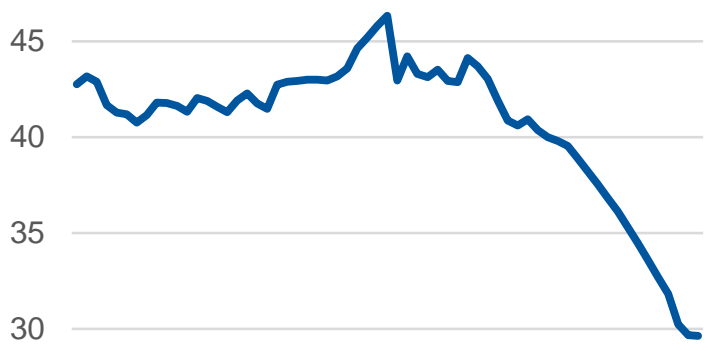

25

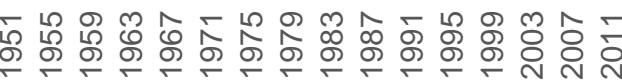

Source: authors' estimates based on data from World Inequality Database.

While there has been some debate over the reliability of inequality estimates based on combining household survey and tax data, ${ }^{13}$ focusing only on the distribution of taxpayers and their share of reported income shows that the concentration of top incomes is very high. In 2015-16, one third of total income accrued to taxpayers with annual incomes of INR 50 million or higher. This group together accounted for only 0.04 per cent of all taxpayers that year. Figure 6 compares the distribution of the number of taxpayers and share of taxable income by income class in 2011-12 and 2015-16.

\footnotetext{
${ }^{13}$ While the method adopted by Piketty and others is similar to those adopted in other countries where tax data have been used to estimate income distribution for the entire population, there have been concerns over the appropriateness of the method (for details, see Atkinson 2007; Leigh 2007; Leigh and Posso 2009; Sutch 2017). In particular, it has been pointed out that, given the low tax base in India, it may underestimate the true extent of inequality.
} 
Figure 6: Distribution of number of taxpayers and income by income class

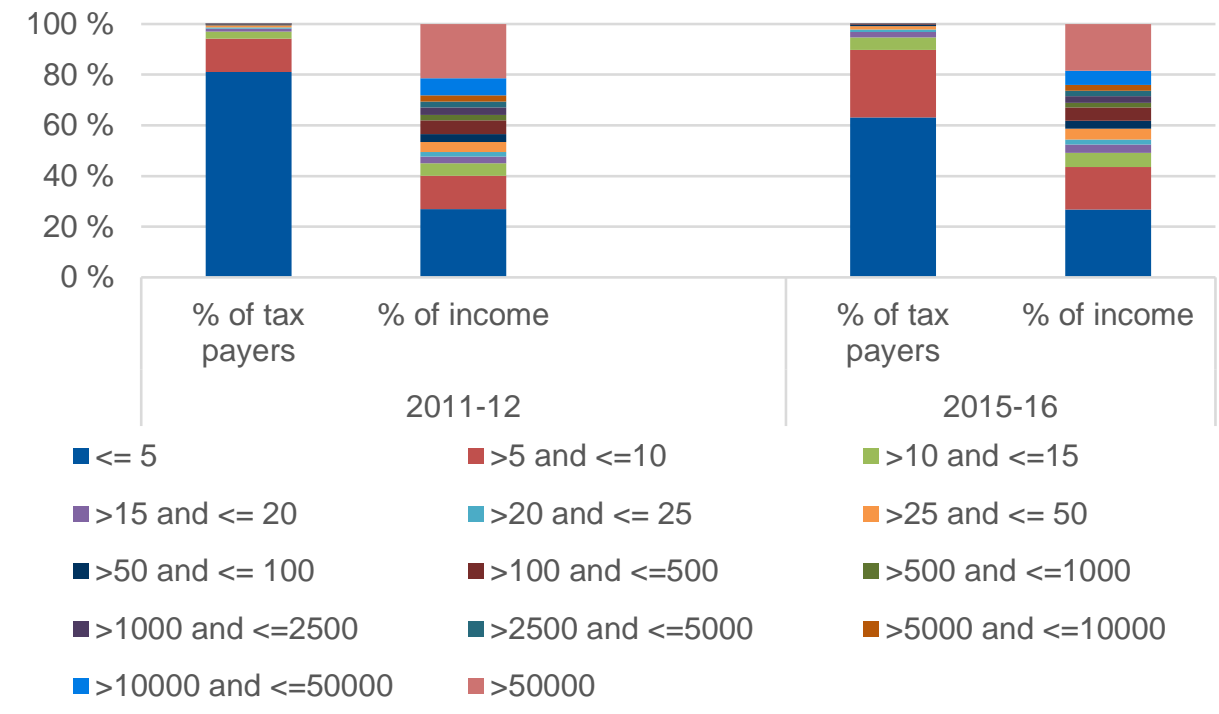

Note: Income classes are in INR 100,000.

Source: authors' calculations based on income tax return data from Government of India, Ministry of Finance.

Direct information on the wealth of billionaires produces similar insights. Gandhi and Walton (2012) use data from Forbes to estimate that the wealth of Indian billionaires was less than five per cent of gross domestic product (GDP) until 2005 but increased sharply to 10 per cent by 2012. By the latest estimates for 2017, the total wealth of Indian billionaires was 15 per cent of GDP. Paradoxically, India is home to the fourth-largest number of billionaires and the largest number of poor people in the world.

\section{Non-monetary inequality: health and education}

India has made substantial gains in health and education outcomes in the past few decades. From 1991 to 2013, life expectancy at birth increased by more than seven years, the infant mortality rate fell by half, the share of births in health facilities more than tripled, the maternal mortality ratio fell by about 60 per cent, and the total fertility rate fell to almost replacement level. The education system also expanded rapidly, leading to gross enrolment ratios of 100 and 95 in primary and upper-primary classes respectively (NUEPA 2015).

On other dimensions, there is mixed progress. While India has outpaced the world in reductions in consumption poverty, progress on nutrition outcomes has been less remarkable. Child stunting (which is associated with poorer socio-economic outcomes in later life), which affected nearly half (48 per cent) of children under five in 2005-06, has reduced, but it still affected 38 per cent of children in 2015-16. Under-five child wasting (weight-for-height) has shown no improvement, stagnating at one fifth of the population. India ranks poorly in global indices such as the Global Hunger Index and the Human Capital Index, reflecting the challenges that remain and the need for sustained progress. ${ }^{14}$

National averages mask disparities across social groups, states, and rural-urban areas, reflecting inequalities in opportunity to access basic services. Figure 7 shows differences in selected health and education outcomes by social group. Although there have been improvements across all social

\footnotetext{
${ }^{14}$ The 2017 Global Hunger Index ranks India $100^{\text {th }}$ out of the 119 countries that are included.
} 
groups, STs and SCs have persistently worse outcomes. ${ }^{15}$ In 2015-16, 44 per cent of ST children under five were stunted, compared with 31 per cent of children from general caste households. Even larger disparities are evident in the rates of underweight children, and those gaps are not closing.

Figure 7: Disparities in human capital outcomes by social group
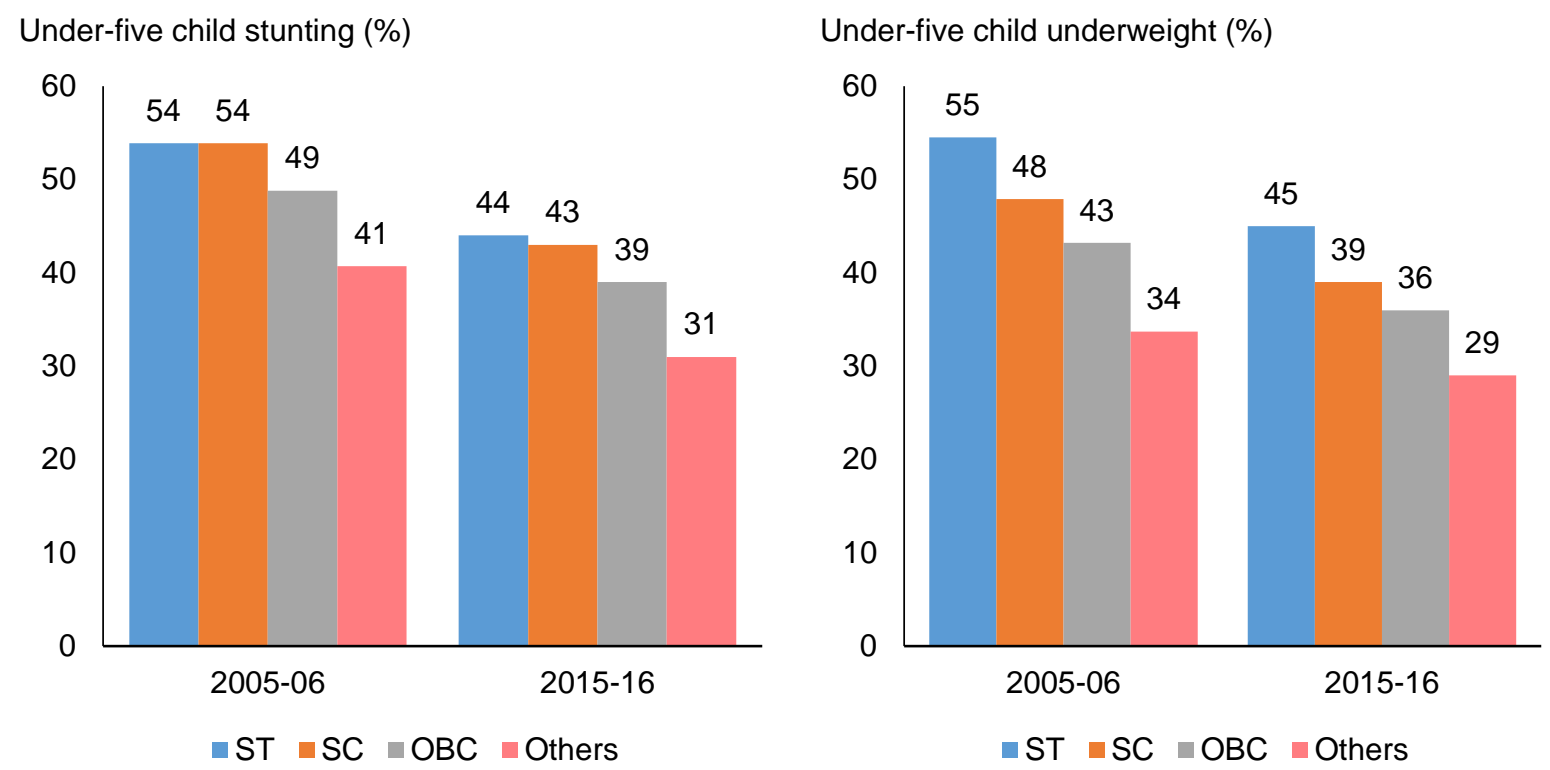

Literacy rates for $7+(\%, 2011)$

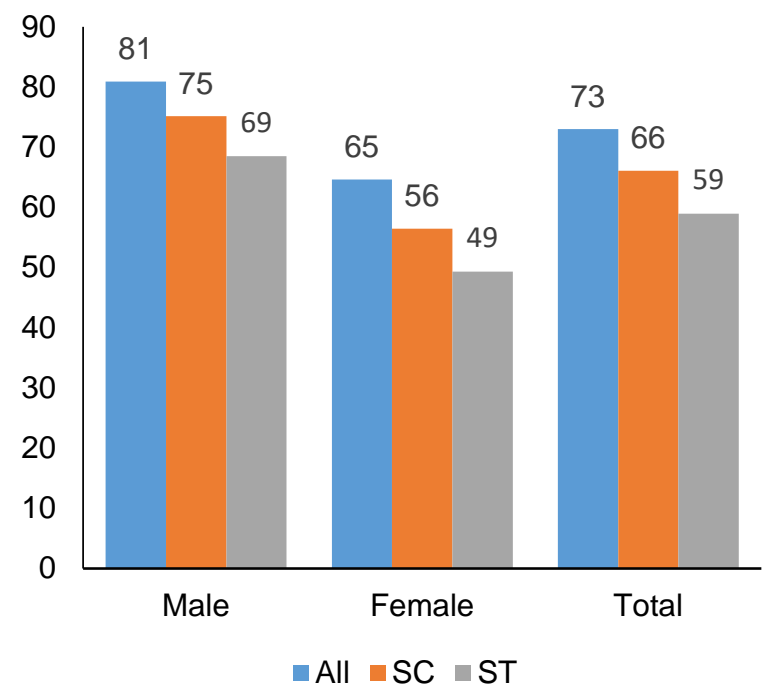

Average annual dropout rates $(\%, 2015)$

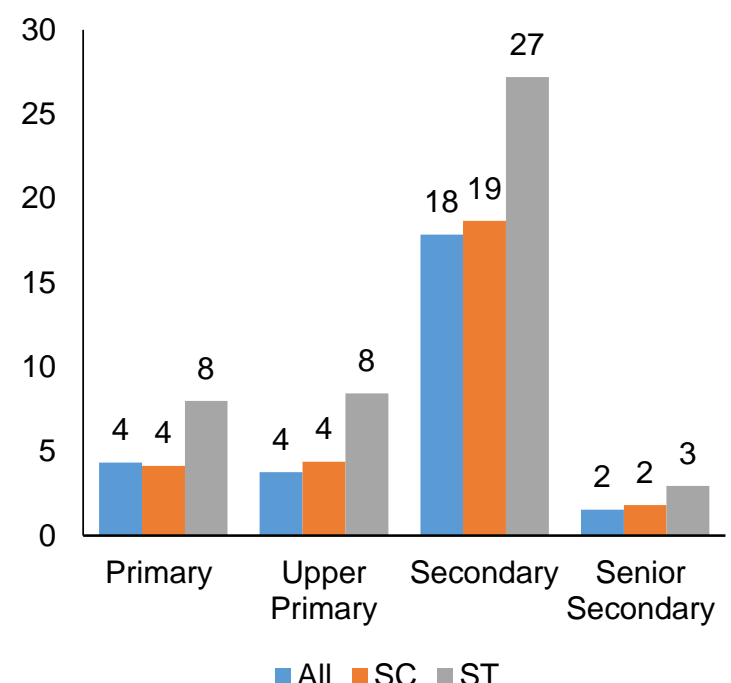

Note: OBC: Other backward castes.

Source: authors' illustration, based on nutrition outcomes from the 2005-06 and 2015-16 National Family Health Surveys (IIPS and Macro International 2007; Ministry of Health and Family Welfare and IIPS 2017), literacy outcomes from the 2011 Indian population census, and dropout rates from NUEPA (2015).

\footnotetext{
15 Thorat and Sabharwal (2011) provide evidence of caste-based disparities in nutrition outcomes throughout the 1990s and early 2000s.
} 
Gaps between social groups are also evident in education outcomes, although outcomes are better in education than in health, and gaps in enrolment rates among school-age children have been closing. Literacy rates have improved for all groups, but in 2011 the literacy rates among SCs and STs were 66 per cent and 59 per cent respectively, compared with a national average of 73 per cent. The disparity between social groups can also be seen in the average annual dropout rates at all levels of school education (Figure 7). Except in primary education, the dropout rates were higher than average for SC children. The rates were much higher for ST children at all levels of school education.

The intersection of gender, location, and social group exacerbates these gaps. In 2011, more than 80 per cent of men were literate, while the rate was only 65 per cent for women. Female literacy among STs is even lower, at below 50 per cent. The literacy rate of rural women is 62 per cent, while the rate is much higher among urban women at 81 per cent. The corresponding rates for men are 83 per cent and 91 per cent respectively.

Opportunities in education are better than in health or sanitation, as measured by the Human Opportunity Index (HOI). ${ }^{16}$ The HOI for access to key services for health and nutrition is below 30 per cent for full immunization or institutional births, and below 40 per cent for improved sanitation (Rama et al. 2015). Access to primary education is far better (the HOI for primary school completion is 80 per cent), reflecting the drive towards universal enrolment and the rising demand for education. The picture is less encouraging for access to secondary school, where the HOI for completion is below 50 per cent. Overall, decompositions of the HOI suggest that parents' education, location, and caste are important circumstances behind inequality in access to health, education, and infrastructure.

\section{$4 \quad$ Structure of inequality}

Where does this review of the evidence leave us? Clearly there was an increase in consumption inequality in the 1990s. But whether that trend continued after the mid-2000s is much less clear. Studies that focus on top incomes suggest large increases; others that rely only on survey data suggest that inequality changes may only have been marginal. All pieces of evidence, by contrast, point to high levels of income, asset, and wealth inequality.

If establishing trends is difficult, explaining them is even more complicated. While causal factors are difficult to establish, in this section we explore the structure of inequality to hint at potential (proximate) factors in changes in inequality over time.

\subsection{Differences across locations}

Differences across states are often pointed to as an important source of rising inequality, given large interstate variations in outcomes. According to 2016-17 economic survey data from the Department of Economic Affairs, eight low-income states (Assam, Bihar, Chhattisgarh, Jharkhand, Madhya Pradesh, Odisha, Rajasthan, and Uttar Pradesh) account for 50 per cent of India's population but 71 per cent of infant deaths, 72 per cent of under-five mortality, and 60 per cent of stunting. Child stunting ranges from two in 10 children in Kerala to about five in 10 in

\footnotetext{
${ }^{16}$ The HOI-computed by multiplying the coverage rate of a service by a measure of the dispersion of access across different population groups - is a synthetic measure of the extent of equality of opportunities. The HOI varies from zero, when nobody has access to services or the dispersion is extremely high, to 100, when everybody has access; it increases when coverage expands or becomes more equitable (Paes de Barros et al. 2009).
} 
Uttar Pradesh and Bihar. ${ }^{17}$ On several of these dimensions (e.g., life expectancy and infant mortality rates) there was convergence across states during the 2000 s, with greater improvements in states that started out worse.

On monetary outcomes the trend is the opposite, with growing regional inequality across Indian states. One way of looking at inequality across states is to estimate the inequality that arises because a person is born in a state, assuming zero inequality within the state. Figure 8 presents interstate inequality, using NAS data on state domestic product. The state domestic product has been divided by the population assuming equal per-capita income within the state, i.e. zero inequality within the state. The resulting Gini coefficient for per-capita income weighted by state population confirms the trend of stable inequality in the 1980s followed by rising inequality since the 1990s.

Figure 8: Per-capita interstate inequality

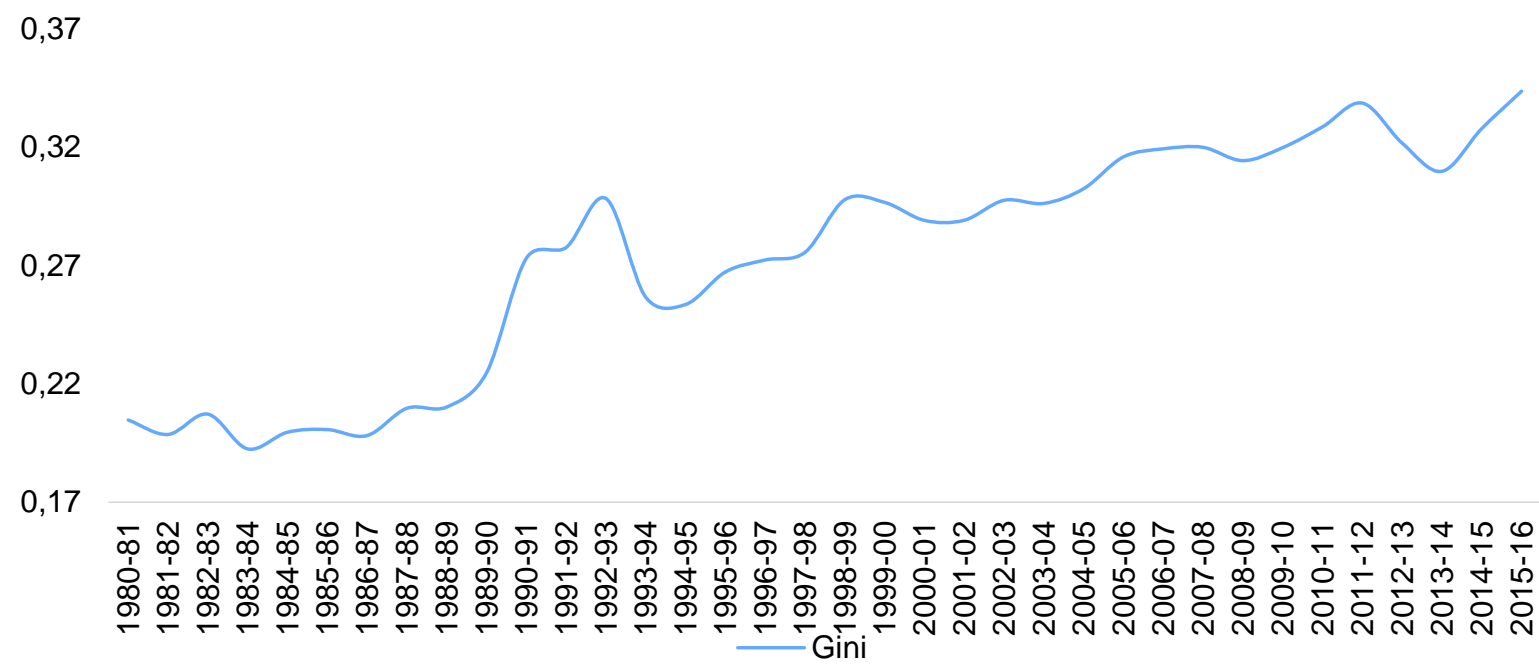

Source: authors' calculations using NAS data.

This result is consistent with Chakravarty and Dehejia (2016), who examine the issue of inequality across 12 major states using NAS data and compare India with regional inequality estimates for other large economies such as the United States, China, and the European Union. They conclude that income disparity across the largest states of India is the widest among similarly large federal economic zones; contrary to global experience of income convergence across and within nations, India shows continuing trends of divergence among its large states; and 1990 seems to be the seminal year of a structural break in income disparity between the richer and poorer large states. In extending the analysis to the district level using night-time light data, Chakravarty and Dehejia (2017) find similar results.

India's rich tradition of detailed village studies shows that state-level estimates mask considerable heterogeneity. Estimates of inequality in a set of village studies by the Foundation for Agrarian Studies in 2005-08 show Gini coefficients ranging between 0.5 and 0.7 (Swaminathan and Rawal 2011). These eight villages (three in Andhra Pradesh, two each in Uttar Pradesh and Maharashtra, and one in Rajasthan) are drawn from different agro-climatic zones. Their results also show a high concentration of wealth in the richest 10 per cent of households. A study in Palanpur village (also in Uttar Pradesh) finds much lower levels of income inequality (0.38 in 2008-09). Overall,

\footnotetext{
${ }^{17}$ More than two thirds of maternal deaths, and more than half of neonatal deaths, occur in four states: Bihar, Madhya Pradesh, Rajasthan, and Uttar Pradesh (Ministry of Health and Family Welfare and IIPS 2017).
} 
comparisons hint that inequality is higher in richer villages, but generalizations should be treated with extreme caution because of differences in methods, time periods, and contexts.

Relatively few studies include comprehensive household consumption or income data over time; the few that exist show rising inequality in recent decades. Swaminathan (1988) reports a rise in inequality in Gokilapuram (Tamil Nadu), from 0.77 in 1977 to 0.81 in 1985. In Palanpur, which has been surveyed once every decade starting in 1957-58, the Gini index of income has risen steadily since the mid-1970s, from 0.27 in 1974-85 to 0.36 in 2008-09 (Himanshu et al. 2016).

\subsection{Differences across social groups}

A natural aspect to consider is differences across social groups-distinguishing, for example, SCs, STs, other backward castes (OBCs), and a residual category of 'others'. This breakdown is far from ideal, as it does not permit any detailed assessments of differences across subgroups within these broad categories. However, no more detailed breakdown of the population is available from the NSS data.

The real MPCE for social groups indicates a higher rate of growth of consumption expenditure for the 'others' category during the period between 1993-94 and 2004-05 than for the ST/SC/OBCs. During the next period (between 2004-05 and 2011-12), however, the growth rates of ST/SC/OBCs increased and caught up with the 'others' category. Despite this increase in growth rates, the ratio of the means of the different categories to the overall mean, which indicates the relative positions of the groups, did not show any significant change.

One way to understand inequality across social and religious groups is to compare their share of income and consumption with that of the overall population. In an equal world, their share of income and consumption and the share of the population will be the same. The ratio of their share of income and consumption over the share of the population then represents the level of inequality. A share of less than one represents disadvantage, whereas a share greater than one would place a group in an advantageous position. Table 5 presents the shares of consumption, income, and asset ownership over the survey years for which such disaggregation is available.

SCs and STs have lower shares of income and consumption compared with the population shares. The OBC group has relatively higher shares of consumption and income, but still less than the population share. Meanwhile, the forward castes have higher shares of income and consumption relative to the population shares. The consumption data also report a decline in income shares for the ST group, with a corresponding increase in the share of 'others'. 
Table 5: Relative shares of consumption, income, and assets, by social group

\begin{tabular}{|c|c|c|c|c|c|c|c|c|}
\hline & \multicolumn{3}{|c|}{ Consumption share/pop. share } & \multicolumn{2}{|c|}{ Income share/ pop. share } & \multicolumn{3}{|c|}{ Asset share/pop. share } \\
\hline & 1993-94 & 2004-05 & 2011-12 & 2004-05 & 2011-12 & 1991 & 2002 & 2012 \\
\hline \multicolumn{9}{|l|}{ All India } \\
\hline ST & 0.76 & 0.69 & 0.69 & 0.68 & 0.67 & 0.48 & 0.49 & 0.40 \\
\hline SC & 0.79 & 0.78 & 0.80 & 0.71 & 0.79 & 0.46 & 0.45 & 0.40 \\
\hline OBC & - & 0.92 & 0.93 & 0.89 & 0.92 & - & 0.90 & 0.83 \\
\hline Others & 1.09 & 1.33 & 1.34 & 1.45 & 1.39 & 1.20 & 1.59 & 1.86 \\
\hline \multicolumn{9}{|l|}{ Rural } \\
\hline ST & 0.83 & 0.76 & 0.77 & 0.75 & 0.72 & 0.51 & 0.54 & 0.50 \\
\hline SC & 0.85 & 0.85 & 0.88 & 0.75 & 0.83 & 0.49 & 0.49 & 0.50 \\
\hline OBC & - & 1 & 1 & 0.95 & 0.96 & - & 0.98 & 1.01 \\
\hline Others & 1.07 & 1.23 & 1.21 & 1.42 & 1.38 & 1.22 & 1.61 & 1.71 \\
\hline \multicolumn{9}{|l|}{ Urban } \\
\hline ST & 0.83 & 0.81 & 0.81 & 1.02 & 1.08 & 0.48 & 0.60 & 0.54 \\
\hline SC & 0.75 & 0.72 & 0.76 & 0.77 & 0.82 & 0.40 & 0.42 & 0.35 \\
\hline OBC & - & 0.83 & 0.85 & 0.84 & 0.87 & - & 0.78 & 0.70 \\
\hline Others & 1.05 & 1.24 & 1.26 & 1.24 & 1.24 & 1.11 & 1.38 & 1.59 \\
\hline
\end{tabular}

Note: OBCs are included in the 'others' category in the asset survey.

Source: authors' estimates based on NSS and IHDS data.

Consistent with the evidence presented earlier regarding high levels of asset inequality, shares of asset ownership relative to the population are particularly poor for SCs and STs. Further, the urban-rural divide is an important factor in understanding the wealth advantage within social groups. The wealth positions of the SC and ST groups in rural areas are similar, but are very different from the wealth positions of the same groups in urban areas. Wealth inequality within each social group increased between 1991 and 2002. For the ST category, it was strong enough to indicate the emergence of a 'creamy layer' within this group (Zacharias and Vakulabharanam 2011), although it remains well below the creamy layer of the forward caste groups.

Table 6 presents a similar analysis for groups defined by religion. Minorities such as Christians have a larger share of income and consumption than the population share, but this is not the case with Muslims. The situation of Muslims is relatively better in rural areas, but they fare worse than SC or ST households in urban areas. Muslims have also seen their share of national income, relative to the population share, decline over time in both rural and urban areas. 
Table 6: Share of income and consumption over share of population by religion

\begin{tabular}{|c|c|c|c|c|c|}
\hline & \multicolumn{3}{|c|}{ Consumption share/pop. share } & \multicolumn{2}{|c|}{ Income share/pop. share } \\
\hline & 1993-94 & 2004-05 & 2011-12 & $2004-05$ & 2011-12 \\
\hline \multicolumn{6}{|l|}{ All India } \\
\hline Hindu & 0.99 & 0.99 & 1 & 0.98 & 0.99 \\
\hline Muslim & 0.91 & 0.91 & 0.87 & 0.92 & 0.91 \\
\hline Christian & 1.23 & 1.41 & 1.39 & 1.74 & 1.52 \\
\hline Others & 1.12 & 1.28 & 1.29 & 1.22 & 1.21 \\
\hline \multicolumn{6}{|l|}{ Rural } \\
\hline Hindu & 0.99 & 0.98 & 0.98 & 0.96 & 0.98 \\
\hline Muslim & 0.95 & 0.98 & 0.94 & 1.03 & 1 \\
\hline Christian & 1.18 & 1.44 & 1.43 & 2.07 & 1.53 \\
\hline Others & 0.95 & 0.98 & 1.05 & 1.19 & 1.24 \\
\hline \multicolumn{6}{|l|}{ Urban } \\
\hline Hindu & 1.02 & 1.03 & 1.04 & 1.03 & 1.03 \\
\hline Muslim & 0.76 & 0.74 & 0.72 & 0.72 & 0.74 \\
\hline Christian & 1.22 & 1.29 & 1.23 & 1.28 & 1.3 \\
\hline Others & 1.15 & 1.33 & 1.18 & 1.29 & 1.33 \\
\hline
\end{tabular}

Source: authors' estimates based on NSS and IHDS data.

Table 7: Asset inequality by religious group

\begin{tabular}{lll}
\hline & Asset share/pop. share & \\
Religious group & 2002 & 2012 \\
Hindu & 0.99 & 1.00 \\
Muslim & 0.65 & 0.57 \\
Christian & 1.58 & 1.67 \\
Sikh & 3.27 & 3.32 \\
Jain & 3.52 & 7.09 \\
Buddhist & 0.58 & 0.57 \\
Others & 0.81 & 0.52 \\
\hline
\end{tabular}

Source: authors' calculations based on the $59^{\text {th }}$ and $70^{\text {th }}$ rounds of AIDIS.

Table 7 reports the asset-share-to-population-share ratio for religious groups. ${ }^{18}$ Similarly to the trend seen in the case of consumption expenditure, minority religious groups such as Christians, Sikhs, and Jains report higher asset shares compared with the population shares. However, Muslims and Buddhists have lower asset-to-population-share ratios compared with any other religious group. For Buddhists, the low asset share is a reflection of a large percentage of SCs who have converted to Buddhism.

Another dimension where India stands out is gender-based inequality. On the positive side, gender gaps in education and nutrition outcomes have been closing over time. While most economic

\footnotetext{
${ }^{18}$ The year 1991 is excluded, as information on religion was not collected in that AIDIS round.
} 
dimensions are household-based and therefore mask the intra-household dimension of inequality, the disadvantaged position of women is most evident in the labour market. India continues to be among the countries with the lowest workforce participation of women; this has shown a decline in recent years.

Chaudhary and Verick (2014) analysed the puzzling phenomenon of a declining female labour force participation rate at a time of high economic growth. During 2004-05 and 2011-12, when GDP grew at eight per cent per annum, the female labour force participation rate declined from an already low 35 per cent to 25 per cent. Although part of this can be explained by increasing female participation in education, that cannot fully explain the decline (Chandrasekhar and Ghosh 2014). The displacement of women from agricultural activities due to mechanization and increasing informalization could be another reason. Gender gaps are also manifest in the gender wage gap, which remains high in almost all categories of occupation (Table 8). Overall, female wages are less than two thirds of male wages in rural areas and have not caught up over time. Gender wage gaps are lower among regular salaried workers in urban areas, but women's wages have not caught up with men's in the decades since the early 1990s.

Table 8: Female/male wage ratio for regular and casual workers

\begin{tabular}{lllll}
\hline & Regular & & Casual & \\
& Rural & Urban & Rural & Urban \\
$1993-94$ & 0.60 & 0.80 & 0.65 & 0.57 \\
$2004-05$ & 0.59 & 0.75 & 0.63 & 0.58 \\
$2007-08$ & 0.62 & 0.77 & 0.67 & 0.57 \\
$2009-10$ & 0.63 & 0.82 & 0.68 & 0.58 \\
$2011-12$ & 0.63 & 0.78 & 0.69 & 0.61
\end{tabular}

Source: author's estimates based on EUS data.

\subsection{Differences by occupation and factor ownership}

Inequality in the labour market also arises from the skewed distribution of workers across sectors, and the differential returns to capital and labour. A large share of the workforce is employed in agriculture (nearly 50 per cent in 2011-12) and the unorganized sector (93 per cent). These are sectors whose share of GDP has been falling, as they have grown more slowly than the national average. Employment in the agricultural sector has been falling less rapidly than its share of income; employment in the unorganized sector has been growing relative to the organized sector. On the other hand, the well-paying sectors that have grown the fastest-such as the finance, insurance, and real-estate sectors, and IT-related services and telecommunications-employ less than two per cent of the workforce. This has led to an increasing divergence between per-worker productivity in sectors such as agriculture and construction and per-worker productivity in the fast-growing sectors. The ratio of labour productivity in the non-agricultural sector to labour productivity in the agricultural sector increased from 4.5 in 1993-94 to 5.5 in 2011-12 (Dev 2017).

Another feature of the labour market is vast differences in the quality of employment. While a large majority of workers are employed in the informal sector, with no social security, the organized sector has also seen a decline in employment quality over the years. Figure 9 gives the distribution of workers by type of employment. At the national level, 93 per cent of all workers are employed as informal workers. These are concentrated in the unorganized sector, but a striking trend in recent decades has been the rise in informal workers in the organized sector. While only 38 per cent of workers were employed as informal workers in the organized sector in 1999-2000, 56 per 
cent were employed as informal workers in the organized sector by 2011-12. Further disaggregation by public and private sectors suggests that the private organized sector contributes a significant proportion of informal workers. The share of informal workers in the organized private sector is almost two thirds.

Figure 9: Percentage of informal workers by type of employment

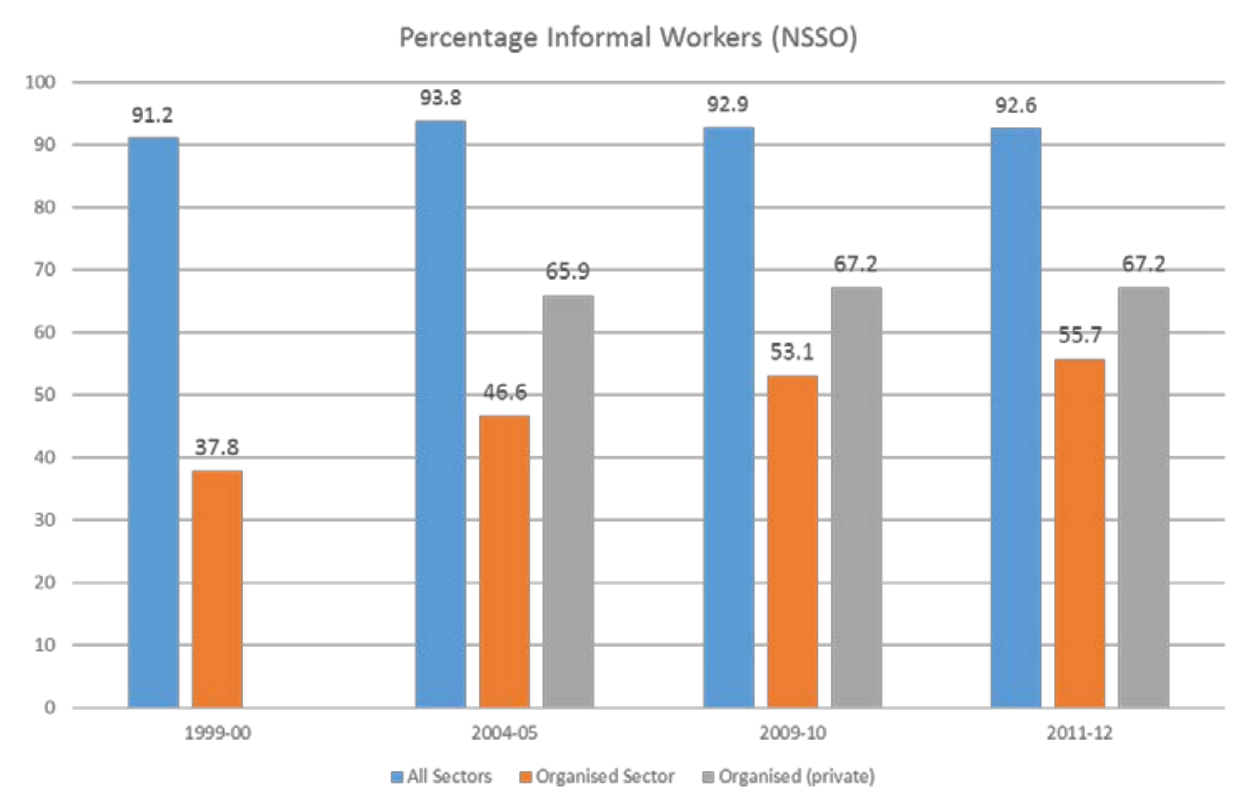

Source: authors' estimates based on NSSO data.

Combining information on the distribution of factor incomes (from NAS data) and workers (from EUS data) provides a rough summary depiction of trends in worker incomes by type of occupation. Figure 10, which reports the distribution of factor incomes by broad categories, shows that the highest increase has been in the share of private surplus (profits), which more than doubled from seven per cent in 1993-94 to 15 per cent in 2011-12. On the other hand, the share of income accruing to cultivators fell from 25 per cent to 14.6 per cent over the same period.

Figure 11, which gives the corresponding employment distributions, shows that the employment structure has changed more slowly than value-added. The workforce has been moving out of agricultural labour and cultivation, into non-farm casual work or self-employment. Regular salaried workers (in either the private or public sector) have maintained roughly the same shares over time.

Combining these two sources of information to compute indices of per-worker income, as in Figure 12, provides some indications of the changing structure of inequality. Between 1993-94 and 2011-12, the highest growth in per-worker incomes is observed among private salaried workers and government salaried workers. Since 1999-2000, the growth of per-worker incomes among private salaried workers and government salaried workers has been almost double that of other workers. There has been some increase and catch-up as far as workers in agriculture are concerned since 2004-05 (reflected in declining wage inequality post-2004-05, as discussed earlier), but over a longer period their incomes have increased by less than half of those of private and government salaried workers. Vakulabharanam (2010) also confirms the unequal gains to different classes of workers, gains to the urban and rural elite being much more than to rural workers and farmers. 
Figure 10: Breakdown of factor incomes

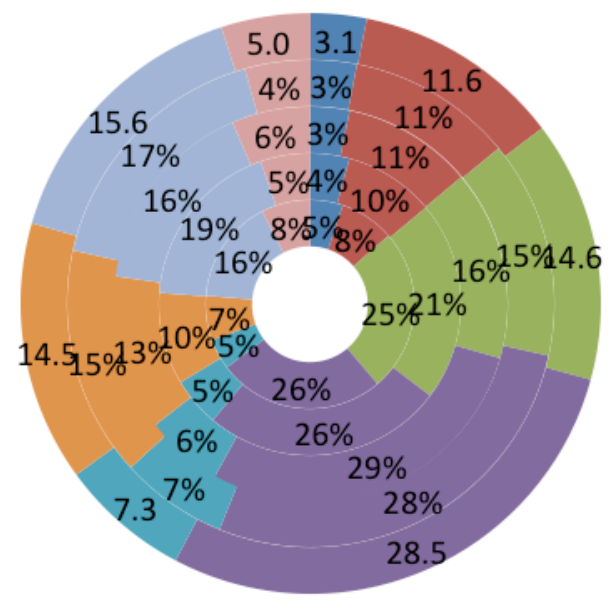

$$
\begin{aligned}
& \text { ag-wages } \\
& \text { nonag wages } \\
& \text { self-emp agri } \\
& \text { self-emp nonagri } \\
& \text { private salaries } \\
& \text { private surplus } \\
& \text { govt salaries } \\
& \text { govt surplus }
\end{aligned}
$$

Innermost:1993-94, Second ring: 1999-00, Third ring: 2004-05, Fourth Ring: 2009-10, Outermost: 2011-12

Source: authors' estimates based on NAS data.

Figure 11: Breakdown of employment by various groups

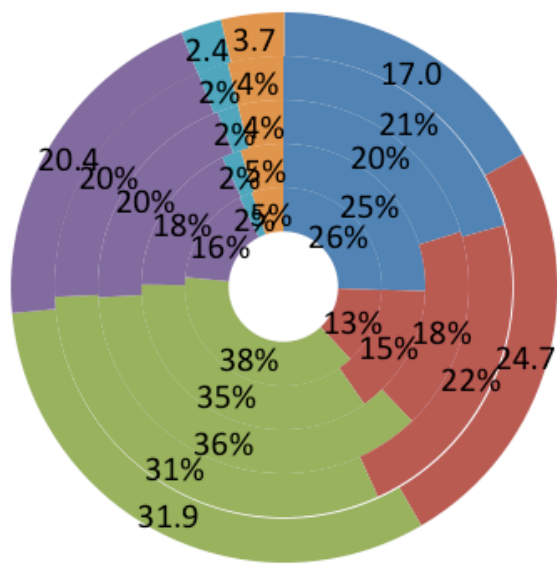

$$
\begin{aligned}
& \square \text { ag-wages } \\
& \square \text { nonag wages } \\
& \square \text { self-emp agri } \\
& \square \text { self-emp nonagri } \\
& \square \text { private salaries } \\
& \square \text { govt salaries }
\end{aligned}
$$

Innermost:1993-94, Second ring: 1999-00, Third ring: 2004-05, fourth ring: 2009-10, Outermost: 2011-12

Source: authors' estimates based on EUS data. 


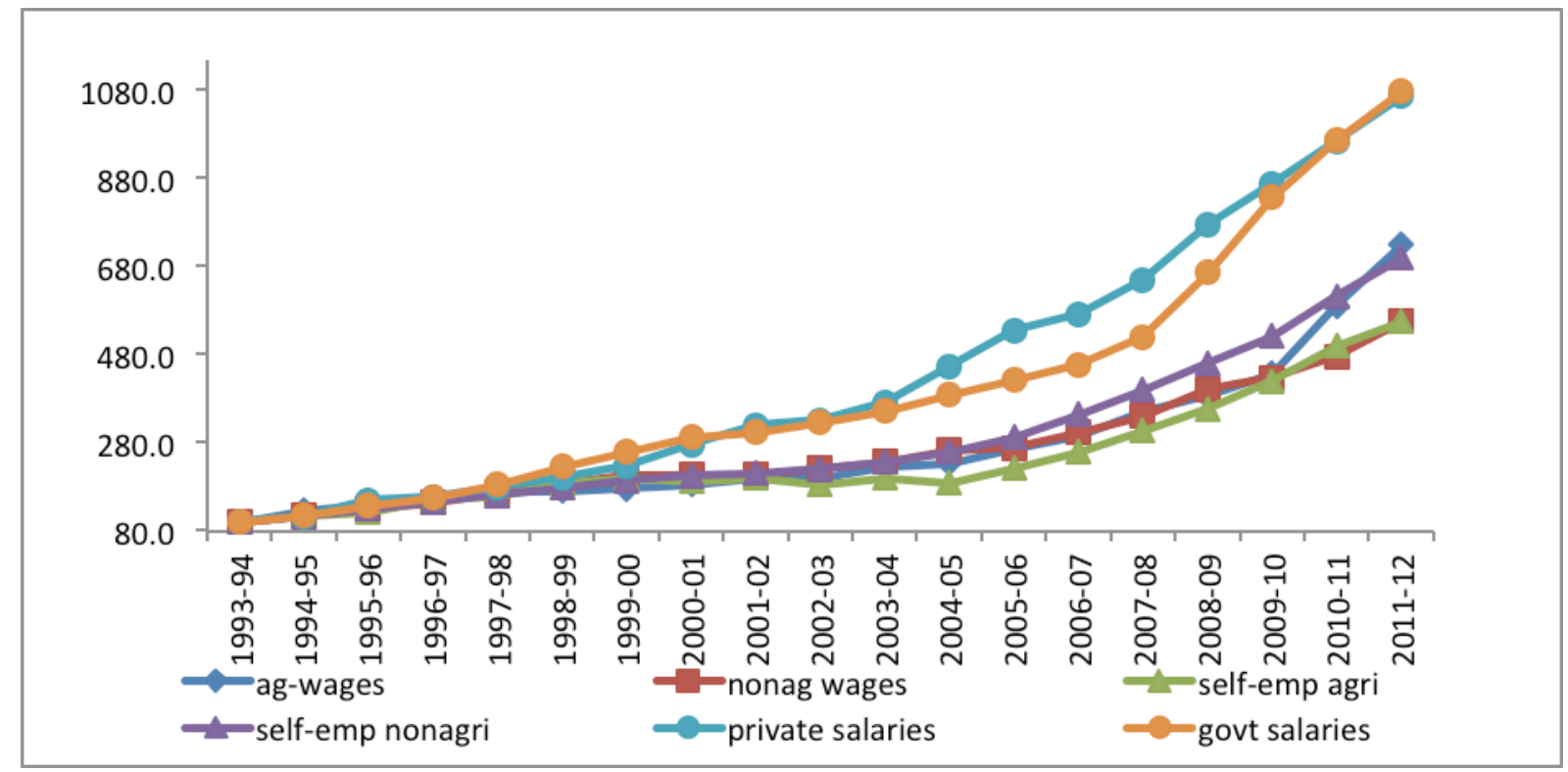

Source: authors' estimates based on NSS and NAS data.

Supporting evidence in this regard is also available from another source of data. The Government of India's Annual Survey of Industries (ASI) collects information on the emoluments received by various categories of workers in the organized manufacturing sector. While workers' wages and the emoluments of managerial staff moved in tandem until the 1980s, they started to diverge in the early 1990s (Figure 13). By 2012, managerial emoluments had increased tenfold, but workers' wages had increased by less than four times.

Figure 13: Wages and profits in organized manufacturing
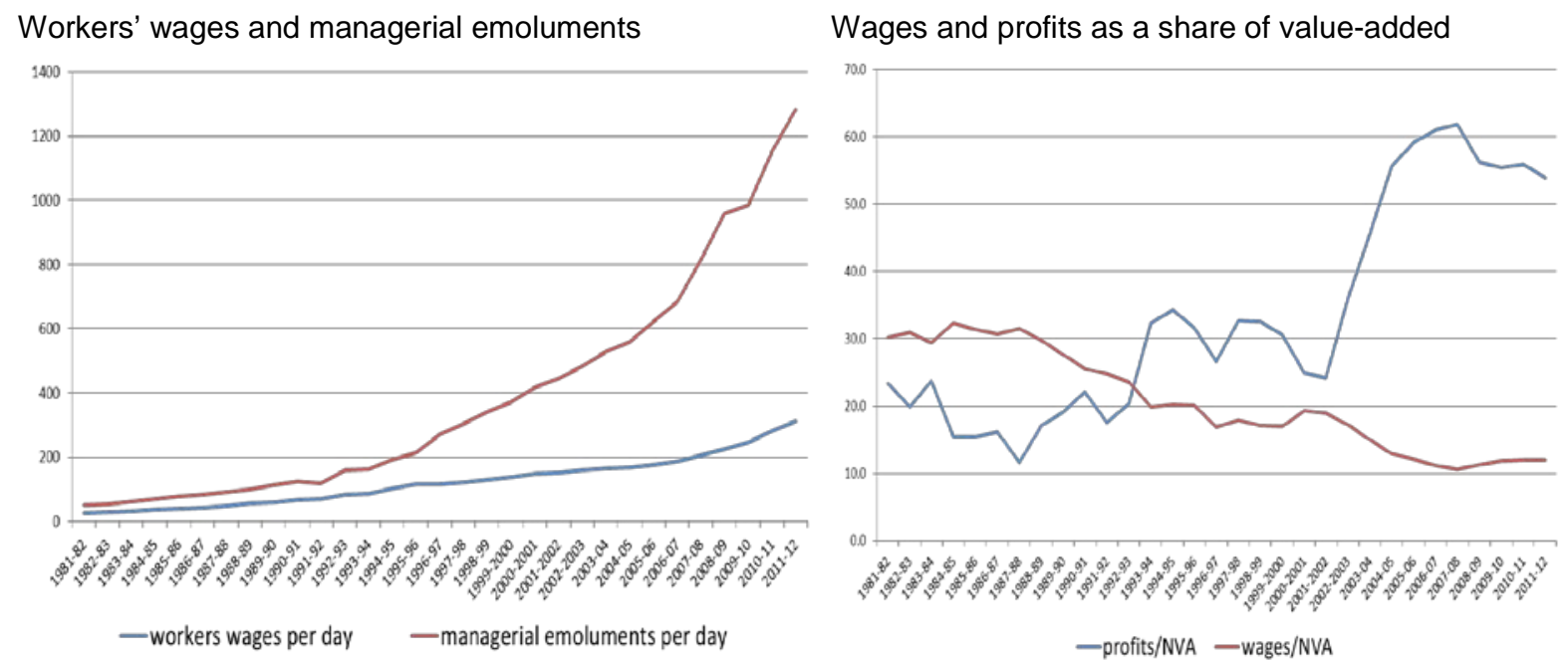

Source: authors' estimates based on ASI data.

The ASI data also shed light on the declining share of value-added that accrued to workers (Figure 13, right-hand panel). While the wage share was higher at around 30 per cent in the early 1980s, with the profit share at only 20 per cent, the shares changed after the 1990s. In recent years, the share of profits in net value-added has increased to more than 50 per cent, reaching a peak of more than 60 per cent in 2007-08. While it declined after the financial crisis, it continues to be above 50 per cent of net value-added in organized manufacturing. During the same period the share of wages in value-added declined to 10 per cent, and it has remained thereabout in recent years. The 
compression in wage share was accompanied by the casualization of the workforce in organized manufacturing. The share of contract workers was less than 20 per cent at the beginning of this century, but had increased to more than one third of the workforce by 2011-12. Contract workers not only suffer from insecurity of tenure but are also paid less, with no social security benefits. This is further confirmed by the data from the EUS.

The increase in inequality among workers in the organized sector is only a small component of overall inequality. But it does emphasize the changing nature of production in the organized sector, with rising profit shares and declining gains to workers.

\section{$5 \quad$ Concluding reflections}

The last three decades have seen an acceleration in the growth rate of national income and a subsequent decline in poverty. However, evidence also shows that the growth has been accompanied by an increase in inequality, possibly in all dimensions. Measures of household inequality, such as the Gini coefficients of consumption expenditure, income, and assets across households, have also shown an increasing trend since 1991. Although there is some moderation in the rate of increase in inequality after 2004-05, current levels of inequality in India put the country among the high-inequality countries.

The inequality has largely been driven by changes in the labour market, with an increasing share of capital at the cost of labour. The rise in profit rate has accompanied a decline in wage share. But it has also been accompanied by rising inequality in access to public services such as health and education. This has led to concerns about crony capitalism. But whether the process of growth will be sustained or not depends not just on economic policies, but also on policies regarding human development and inclusion.

While rising inequality may have consequences for political stability and the sustainability of economic growth, it also affects the mobility of individuals. Outcomes for growth and human development are not only determined by the existing state of income distribution, but are also determined by where an individual is born and to which caste, community, religion, region, and gender. These affect equal access to opportunities because of the persistence of horizontal inequalities that subject individuals to prejudice, marginalization, discrimination, or disadvantage. Identities such as gender, caste, or community affect an individual's participation in the labour market, in isolation from but also in conjunction with other identities. These are also affected by political and economic forces, and result in access to or denial of opportunities. 


\section{References}

Atkinson, A.B. (2007). 'Measuring Top Incomes: Methodological Issues'. In A.B. Atkinson and T. Piketty (eds), Top Incomes Over the Twentieth Century: A Contrast Between Continental European and English-Speaking Countries. Oxford and New York: Oxford University Press.

Atkinson, A.B. (2015). Inequality: What Can Be Done? Cambridge, MA: Harvard University Press.

Banerjee, A., and T. Piketty (2005). 'Top Indian Incomes, 1922-2000’. World Bank Economic Review, 19(1): 1-20.

Chakravarty, P., and V. Dehejia (2016). 'India’s Curious Case of Economic Divergence'. Briefing Paper 3. Mumbai: IDFC Institute.

Chakravarty, P., and V. Dehejia (2017). 'Will GST Exacerbate Regional Divergence?’ Economic and Political Weekly, 52(25-26): 97-101.

Chakravorty, S., S. Chandrasekhar, and K. Naraparaju (2016). 'Income Generation and Inequality in India's Agricultural Sector: The Consequences of Land Fragmentation'. Working Paper 2016-028. Mumbai: Indira Gandhi Institute of Development Research.

Chancel, L., and T. Piketty (2017). 'Indian Income Inequality, 1922-2014: From British Raj to Billionaire Raj?’ Discussion Paper 12409. London: CEPR.

Chandrasekhar, C.P., and G. Jayati (2014). 'Growth, Employment Patterns and Inequality in Asia: A Case Study of India'. ILO Asia-Pacific Working Paper Series. Bangkok: ILO Regional Office for Asia and the Pacific.

Chaudhary, R., and S. Verick (2014). 'Female Labour Force Participation in India and Beyond'. ILO Asia-Pacific Working Paper Series. Bangkok: ILO Regional Office for Asia and the Pacific.

Crabtree, J. (2018). The Billionaire Raj: A Journey Through India's New Gilded Age. London: Oneworld Publications.

Credit Suisse Research Institute (2016). 'Global Wealth Report 2017'. Zürich: Credit Suisse AG.

Datt, G, M. Ravallion, and R. Murgai (2016). 'Growth, Urbanization, and Poverty Reduction in India'. Policy Research Working Paper 7568. Washington, DC: World Bank.

Dev, M. (2017). 'Inequality, Employment and Public Policy'. Presidential address, 59 $9^{\text {th }}$ annual conference of the Indian Society of Labour Economics, 16-18 December, Thiruvananthapuram.

Gandhi, A., and M. Walton (2012). 'Where Do India's Billionaires Get Their Wealth?’ Economic and Political Weekly, 47(40): 10-14.

Himanshu (2007). 'Recent Trends in Poverty and Inequality: Some Preliminary Results'. Economic and Political Weekly, 42(6): 497-508.

Himanshu (2015). 'Inequality in India'. Seminar, 672: 30-35.

Himanshu (2018). 'Growth, Structural Change and Wages in India: Recent Trends'. Indian Journal of Labour Economics, 60(3): 309-31.

Himanshu, B. Joshi, and P. Lanjouw (2016). 'Non-Farm Diversification, Inequality and Mobility in Palanpur'. Economic and Political Weekly, 51(26-27): 43-51.

IIPS and Macro International (2007). 'National Family Health Survey (NFHS-3), 2005-06: India: Volume I'. Mumbai: IIPS. 
IMF (2017). 'Fiscal Monitor October 2017: Tackling Inequality’. Washington, DC: IMF.

Jayadev, A., S. Motiram, and V. Vakulabharanam (2007). 'Patterns of Wealth Disparities in India During the Liberalisation Era'. Economic and Political Weekly, 42(38): 3853-63.

Kanbur, R., C. Rhee, and J. Zhuang (eds) (2014). Inequality in Asia and the Pacific: Trends, Drivers, and Policy Implications. Abingdon and New York: Routledge.

Lange, G.-M., Q. Wodon, and K. Carey (eds) (2018). The Changing Wealth of Nations 2018: Building a Sustainable Future. Washington, DC: World Bank.

Leigh, A. (2007). 'How Closely Do Top Income Shares Track Other Measures of Inequality?' Economic Journal, 117(524): 619-33.

Leigh, A., and A. Posso (2009). 'Top Incomes and National Savings'. Review of Income and Wealth, 55(1): 57-74.

Li, H., L. Squire, and H. Zhou (1998). 'Explaining International and Inter-Temporal Variation in Income Inequality'. Economic Journal, 108(446): 26-43.

Mazumdar, D., S. Sarkar, and B.S. Mehta (2017a). Inequality in India I'. Economic and Political Weekly, 52(30): 47-56.

Mazumdar, D., S. Sarkar, and B.S. Mehta (2017b). 'Inequality in India II: The Wage Sector'. Economic and Political Weekly, 52(32): 58-66.

Milanovic, B. (2016). Global Inequality: A New Approach for the Age of Globalization. Cambridge, MA: Harvard University Press.

Ministry of Health and Family Welfare and IIPS (2017). 'National Family Health Survey (NFHS4) Fact Sheet'. New Delhi and Mumbai: Ministry of Health and Family Welfare and IIPS. Available at: http://rchiips.org/nfhs/pdf/NFHS4/India.pdf (accessed 19 December 2018).

NUEPA (2015). 'School Education in India, U-DISE 2014-15 (Provisional Estimates)'. New Delhi: National University of Educational Planning and Administration. Available at: http://dise.in/Downloads/Publications/Documents/U-DISE-SchoolEducationInIndia2014-15.pdf (accessed 19 December 2018).

Paes de Barros, R., F. Ferreira, J. Molinas Vega, and J. Saaevdra (2009). Measuring Inequality of Opportunities in Latin America and the Caribbean. Washington, DC: World Bank.

Piketty, T. (2014). Capital in the 21st Century. Cambridge, MA: Belknap Press.

Rama, M., T. Béteille, Y. Li, P.K. Mitra, and J.L. Newman (2015). Addressing Inequality in South Asia. Washington, DC: World Bank.

Rodgers, G., and V. Soundararajan (2015). 'Patterns of Inequality in India, 1983-2011/12: Project Paper D (India)'. Delhi: Institute for Human Development.

Sarkar, S., and B.S. Mehta (2010). 'Income Inequality in India: Pre- and Post-Reform Periods'. Economic and Political Weekly, 45(37): 45-55.

Sen, A., and Himanshu (2004). 'Poverty and Inequality in India II: Widening Disparities During the 1990s'. Economic and Political Weekly, 39(39): 4361-75.

Stewart, F. (2002). 'Horizontal Inequalities: A Neglected Dimension of Development'. QEH Working Paper Series 81. Oxford: University of Oxford, Department of International Development.

Stiglitz, J. (2012). The Price of Inequality: How Today's Divided Society Endangers Our Future. W.W. Norton \& Co. 
Subramanian, S., and D. Jayaraj (2006). 'The Distribution of Household Wealth in India'. Research Paper 2006/116. Helsinki: UNU-WIDER.

Sutch, R. (2017). 'The One Percent Across Two Centuries: A Replication of Thomas Piketty's Data on the Concentration of Wealth in the United States'. Social Science History, 41(4): 587613.

Swaminathan, M. (1988). 'Growth and Polarisation: Changes in Wealth Inequality in a Tamilnadu Village'. Economic and Political Weekly, 23(43): 2229-34.

Swaminathan, M., and V. Rawal (2011). 'Is India Really a Country of Low Income-Inequality? Observations from Eight Villages'. Review of Agrarian Studies, 1(1). Available at: http://ras.org.in/is_india_really_a_country_of_low_income_inequality_observations_from _eight_villages (accessed 19 December 2018).

Thorat, S., and N.S. Sabharwal (2011). 'Addressing the Unequal Burden of Malnutrition'. India Health Beat, 5(5). Available at: http://www.bpni.org/Article/Policy-Note-Number-5.pdf (accessed 19 December 2018).

Vaidyanathan, A. (1993). 'Asset Holdings and Consumption of Rural Households in India: A Study of Spatial and Temporal Variations'. In Indian Society of Agricultural Economics (ed.), Agricultural Development Policy: Adjustments and Reorientation. New Delhi and Oxford: Indian Society of Agricultural Economics.

Vakulabharanam, V. (2010). 'Does Class Matter? Class Structure and Worsening Inequality in India'. Economic and Political Weekly, 45(29): 67-76.

World Bank (2016). 'Poverty and Shared Prosperity 2016: Taking on Inequality'. Washington, DC: World Bank.

World Bank (2018). 'Poverty and Inequity Database'. Washington, DC: World Bank. Available at: http://databank.worldbank.org/data/reports.aspx?source=poverty-and-equity-database (accessed 26 November 2018).

World Inequality Lab (2018). World Inequality Report 2018. World Inequality Database.

Zacharias, A., and V. Vakulabharanam (2011). 'Caste Stratification and Wealth Inequality in India'. World Development, 39(10): 1820-33. 